\title{
Hicret K. Toprak, Mihrap, Minber ve Devlet: Tek Parti Döneminde Diyanet İşleri Başkanlığı, İstanbul: Küre Yayınları, 2019, 359 s.
}

Değerlendiren: Ayşe Polat

Ankara Sosyal Bilimler Üniversitesi Din Sosyoloji Doktor Öğretim Üyesi Hicret K. Toprak'in Mihrap, Minber ve Devlet: Tek Parti Döneminde Diyanet İ̧sleri Başkanlığı başlıklı kitabı, 2019 yılında Küre Yayınları tarafından yayınlanmıştır. Eserin alt başlığının (Tek Parti Döneminde Diyanet İşleri Başkanlığı) kısmen yanıltıcı olduğu, yazarın salt bir kurum çalışması ortaya koymayıp Cumhuriyet'in inşa sürecinden 1950'ye kadar Türkiye'de din-devlet ilişkisini çeşitli boyutlarıyla ele aldığ belirtilebilir.

Toprak, Diyanet İşleri Reislik/Başkanlığı'nın isminin belirlenmesinden (s. 84) kuruluşuna dair kanun teklifi ve teşkilat kanununa (ss. 85-87), bütçe yetersizliğinden (ss. 91-93) ilk reislerin kimler olduğuna (s. 90) ve onların görüşlerine -sırayla ağırlıklı olarak Ahmet Hamdi Aksekili, Rıfat Börekçi ve Şerefeddin Yaltkaya'nınki olmak üzere- varıncaya kadar önemli tespitler ortaya koymaktadır. Öte yandan Toprak, eser boyunca dinî alana yönelik resmî, kurumsal, hukuki düzenlemeleri ve bunların gündelik hayatta uygulanma biçimlerini ve gördüğü tepkileri irdelemektedir. Toprak, kitabın iki ana bölüm başlğıından (Dinî Hayatın Düzenlenmesi ve Dinî Hayatın Denetimi) da anlaşılabileceği üzere Türkiye'de laik sistemin din ve devlet alanlarının birbirinden kesin çizgilerle ayrıştırılmasından ziyade devletin dinî alanı düzenleme ve denetleme şeklinde işleyiş biçimlerine vurgu yapmaktadır.

Toprak, "dinî hayat" ifadesini açıp tanımlamamaktadır. Ancak hilafetten medreselere, camilerden Kur'an Kursları ve tekkelere, dinî yayınlardan müfredata, ibadet dilinden din tasavvuruna geniş bir spektrumda ele aldığ konulardan dinin ve "dinselliğin" (s. 30) kurumsal, materyal ve imgesel görünümlerini kast ettiği çıkarımı yapılabilir. Toprak, "dinî hayat" ve laik politikaların şekillenmesinde iki gru-

@ Dr. Öğretim Üyesi, İstanbul Medeniyet Üniversitesi. polatayse@gmail.com

(iD) https://orcid.org/0000-0002-8739-6372 
bun rolünü öne çıkarmaktadır: Mustafa Kemal Atatürk başta olmak üzere dönemin kurucu siyasi kadrosu ve Diyanet İşleri Reisleri başta olmak üzere dinî bürokratik kurum ve kadrolar. Toprak'ın dinî hayatın dönüşümünü siyasi ve dinî elitler üzerinden ele aldığı şeklinde bir eleştiri akla gelebilir. Lakin bu sınırlamanın kitabın temel konu ve yaklaşımı ile uygun ve tutarlı olduğu belirtilmelidir. Ayrıca Toprak'ın araştırmasını sırf Diyanet İşleri üst bürokratları ile sınırlı tutmayıp farklı hoca ve imamların ("din görevlilerinin”) dinî değişim ve sürekliliğe dair görüş ve uygulamalarına yer verdiği, resmî kaynakların yanı sıra dönemin gazete ve dergileri gibi gayriresmî ve gündelik kaynakları kullandığı da hatırlatılmalıdır.

Yazar, erken Cumhuriyet döneminde din politikalarının tekdüze olmadığını, dönemler arası ve dönem içi önemli farklılıklar olduğunu vurgulamaktadır. Bu açıdan Toprak 1924-1945 ve 1946-1950 dönemleri arasındaki önemli farklılıklara (s. 16) işaret ettiği gibi "geçiş dönemi” olarak adlandırdığı bir evre (kitapta belirtilmese de bu tabirin kullanıldığı ilk bölümden 1919-1924 yıllarına tekabül ettiği anlaşılmaktadır) ile daha sonraki yıllar arasındaki dönüşüme de dikkat çekmektedir. Din, geçiş döneminde devlet tarafından siyasi mücadele için "araçsallaştırılırken" (s. 47) sonra bundan uzaklaşılıp (s. 88) din-siyaset ayrışması ve laik politikaları daha öne çıkarılmıştır. Her hâlükârda Cumhuriyet'in kuruluş aşamasından 1950'ye uzanan dönemde devletin dinî alanı yönetmesinde, Toprak’a göre düzenleme ve denetim mekanizmaları baskın olmuştur.

$\mathrm{Bu}$, gerek ibadet dilinin Türkçeleştirilmesi olsun gerekse kılık kıyafet düzenlemeleri gibi "devrim kanunları" noktasında olsun devletin dinî bir muhalefet ile karşılaşmadığı anlamına gelmemiştir ki Toprak da eserinde bunları detaylı olarak ele almaktadır (Örneğin; Türkçe ezan okunmasına karşı çeşitli illerde çıkmış olaylar ve bunların yargılanma süreci hakkında bkz. ss. 246-248). Toprak'ın kitabının ana çerçevesi kapsamında Diyanet İşleri Başkanlığı'nın “devlet” ve "din” arasında kalışının, ikisi tarafından hem teşekkül ettirilip hem sınırlandırılışının ve kurumun bazen ikisini de zorlayan reform/muhalefet ve devamlılık inşa çabalarının anlatısını ortaya koymaya çalıştığı bile öne sürülebilir. ${ }^{1}$

Mihrap, Minber ve Devlet farklı disiplinlerde; Türkiye'de din-siyaset ilişkisi, din politikaları, dinî reform, kurumsal din gibi konular üzere gerçekleştirilen çalışmalara önemli katkılar sunmaktadır. Kitabın çok zengin bir birincil kaynak araştırma-

1 Bu noktada en çarpıcı örneklerden biri Rıfat Börekçi'nin şapkanın dindeki yerini hem hadis hem "asri” din anlayışı noktasında meşrulaştırma çabasıdır (s. 212). 
sına dayalı olduğu vurgulanmalıdır. Toprak, Başbakanlık Cumhuriyet Arşivi ve Din İşleri Yüksek Kurulu Arşivi'nde şimdiye kadar kullanılmamış gerek doğrudan Diyanet İşleri Başkanlığı gerekse Bakanlar Kurulu gibi ilintili kurumlara ilişkin defter ve katalogları inceleyerek bulgularına ulaşmıştır (ss. 15-16). Bunun yanı sıra TBMM Zabıt Cerideleri ve Vakıflar Genel Müdürlüğü Mecmuası gibi kurumsal ve resmî yayınlar ile Cumhuriyet, Vakit, Akşam başta olmak üzere dönemin gazetelerinden de önemli ölçüde yararlandığı görülmektedir. Bu kitabın orijinal, çeşitli ve zengin kaynakları ile 1923-1950 arası Türkiye'de din ve devlet konusuna ilgi duyan araştırmacılar için bir başvuru kaynağı olabileceği öngörülebilir. Örneğin; dinî yayıncılık ve matbuat konusuna merak duyan araştırmacılar, kitabın ilgili bölümlerinden istifade edebilir (ss. 178-185, 291-334).

Ancak belki de tam bu zengin kaynak kullanımına binaen Mihrap, Minber ve Devlet'in organizasyon, kaynak ve yöntem eksikleri barındırdığı da vurgulanmalıdır. Öncelikle Toprak'ın kullandığı kaynaklara sadece önsözde ve çok sınırlı olarak (ss. 15-16) değinmesi yetersiz olduğu gibi eserin bir yöntem tartışması içermemesi de çarpıcıdır. Yazar, nasıl ve hangi biçimde gerek arşiv gerekse yazılı kaynaklarda tarama yaptığını açıklamamıştır. Ayrıca kullandığı birincil kaynakları özellikle daha önce tasnif edilmemiş olan Müşavere Heyeti Karar Defterleri gibi kaynakları, okuyucuya daha kapsamlı tanıtması beklenmektedir. Kitapta ara ara bu kaynakların görsellerinin paylaşılması bu noktada faydalı ancak yetersizdir. Benzer bir şekilde kitapta bahsi geçen önemli bazı kişilerin kısa bir tanıtımının yapılması ele alınan konunun önemini daha iyi ortaya koyabilirdi. ${ }^{2}$

Literatür taraması ve ikincil kaynak kullanımı noktasında da mevcut başka çalışmalardan yararlanılmakla beraber kaynak ve analiz noktasında bazı eksikler görülmektedir. Kitapta Mete Tunçay'ın Türkiye Cumhuriyeti’nde Tek Parti Yönetimi'nin Kurulması ve G. Jäschke'nin Yeni Türkiye'de İslamlık eserleri ağırlıklı olarak öne çıkarken bu devirle ilgili farklı ikincil kaynak ve analizlerden çok sınırlı ölçüde yararlanılmıştır. Bu açıdan kitapta değinilen alt başlıklarla ilgili çalışmalar da tam kapsayıcı olarak taranmamıştır. ${ }^{3}$ Meclislerinde başkanlık yapmış öne çıkan bir isim olduğu bilgisi okurla paylaşılmamaktadır (s. 79). çalışmalarına değinilmiş ancak konuyla ilgili yakın dönemde ortaya konup Türkçeye de çevrilmiş olan Brett Wilson'ın Milliyetçilik Çağında Kuran Tercümeleri eserinden hiç bahsedilmemiştir. 
Mihrap, Minber ve Devlet, tarihsel materyal üzerinden bir inceleme ise Toprak'in son dönem Osmanlı ve erken dönem Cumhuriyet tarih yazımında öne çıkan devamlılık-kopuş teması gibi Osmanlı'dan Cumhuriyet'e dinî alanın denetim ve düzenlenmesindeki benzerlik ve farklılıklara değinmesi yararlı olacaktı. Yazar, bunu giriş bölümünde kısmen yapmaya çalışsa da bu kitabın diğer kısımlarına yansımadığı gibi o bölümde de tam ikna edici şekilde gerçekleştirilmemektedir. Örneğin; burada ve kitabın başka yerlerinde ele alınan Cumhuriyet dönemindeki "hurafe", "batıl itikat" eleştirileri ve İslam'ın rasyonel bir din olarak tasavvuru (s. 36), son dönem Osmanlı'daki benzer tartışmalardan nasıl ayrışmaktadır? Bu ve bunun gibi devamlılık ve farklılığa dair sorulabilecek pek çok soru ve bu sorunsalın kendisi eserde açllmamaktadır.

Buna paralel olarak kitapta birincil ve ikincil kaynaklardan aktarımlar bazen salt alıntılama şeklinde öne çıkıp derinlikli bir inceleme ve tartışma söz konusu olmamaktadır. Örneğin; Amit Bein'in Osmanlı Uleması ve Türkiye Cumhuriyeti Değişimin Failleri Geleneğin Muhafizları isimli eseri dipnotta belirtilmiş (s. 187) ancak bu eserin argümanları ile yazarın bu kitaptaki tespitleri karşılaştırılmalı bir şekilde tartışılmamıştır. Birincil kaynaklar açısından da kitabın özellikle "Dinî Hayatın Düzenlenmesi” başlıklı ikinci bölümü çok çarpıcı, zengin bir muhteviyata sahiptir ancak birincil kaynak alıntıları genelde sadece çok kısa tahliller ile okura sunulmaktadır.

Toprak, kitabı düzenleme ve denetleme şeklinde iki ana eksen etrafında kurgulamış olmakla beraber bu yetersiz kalmıştır. Düzenleme ve denetlemenin tanımlanıp ayrıştırılması, iç içe geçmişliklerinin tartışması yapılmadığı için aynı konular (ibadet dili, hutbe, ezan, dinî yayın gibi) ikinci ve üçüncü bölümde ele alınmaktadır. Her ne kadar Toprak bu bölümlerde farklı örnekler verse de kitabın bölümlerinin organizasyonu sadece düzenleme ve denetleme gibi ikili bir eksende kurulmayıp daha analitik veya tematik bir organizasyon yapılmış olabilseydi ana bölümlerde de aynı bölüm içindeki alt başlıklandırmalarda da ele alınan konular daha bütünlüklü ve daha az tekrarlı bir şekilde işlenmiş olabilirdi.

Toprak tarihsel bir malzeme üzerinden bir dönem ve kurum okuması gerçekleştiriyor ise de eseri, din sosyolojisi başta olmak üzere sekülerleşme konusunu inceleyen pek çok akademisyen için önemli bulgu ve tespitler barındırmaktadır. Bu noktada Toprak'ın bu ampirik araştırmayı sekülerleşme literatürü ile daha doğrudan bağlantılı olarak ele alması, laikliğin sadece Türkiye'de değil Fransa dâhil olmak üzere farklı ülkelerde de denetim ve düzenleme mekanizmalarına dayalı işleyişini mukayeseli ele alışı, çalışmasının tarih disiplini ile sınırlı kalmamasını sağlayacaktır. 
Mihrap, Minber ve Devlet'in bir başlangıç eseri olduğu öne sürülebilir. Pek çok kaynağa dayalı olarak ve bu kaynakları ilk inceleyen çalışma olması sebebiyle bazı organizasyon ve analitik eksiklikler barındırması belki de kaçınılmazdır. Ancak Türkiye'de din, devlet, toplum ilişkilerinin tezahürlerini, Diyanet İşleri Başkanlığı'nın ilk yirmi beş yıllık serüvenini merak eden akademik ve genel okuyucu, bu kitapta gerek dinin kurumsallaştırılması, devletin dinî alanı yönetme biçimleri ve toplumsal tepkiler gibi önemli temalar gerekse somut, ampirik, matbu ve resmî kaynak verilere dayalı çarpıcı örnekler bulabilecektir. Kitabın bu noktada zihinlerde pek çok yeni soru ve araştırma konusunu tetiklediği ve bu açıdan önemli bir akademik katkı sağladığı belirtilmelidir. 